\title{
PENDIDIKAN KELUARGA MENURUT ISLAM
}

\author{
Hafidz $^{1}$, Rizky Kurnia Ahmad ${ }^{2}$, Ajeng Vivi Santika ${ }^{3}$ \\ Sekolah Tinggi Ilmu Tarbiyah Madani Yogyakarta \\ Hafidz_mpdi@yahoo.com
}

\begin{abstract}
Abstrak
Tujuan penelitian ini yaitu menjelaskan konsep pendidikan keluarga menurut Islam baik dari tujuan hingga metode yang dipergunakan dalam mendidik anggota keluarga. Metode dalam penelitian ini adalah kualitatif deskriptif dengan jenis kepustakaan (library research)yang bersifat analitis deskriptif. Teknik pengumpulan data menggunakan teknik dokumentasi dan dianalisis melalui analisis isi. Hasil penelitian ini menyimpulkan 1) tujuan pendidikan Islam dalam keluarga ialah untuk menegakkan syariat islam dalam menyelesaikan masalah keluarga,Mewujudkan ketenangan psikologis,dan memenuhi kebutuhan cinta kasih anak, 2) metode pendidikan islam dalam keluarga meliputi keteladanan, pembiasaan serta latihan, memberi nasehat,dan pengawasan. Dapat disimpulkan bahwa orang tua mempunyai tanggung jawab besar dalam mendidik, khususnya di dalam melindungi keluarga dan memelihara keselamatan keluarga,dan semua itu akan sukses jika dilakukan dengan berlandaskan pada syariat Islam(pendidikan Islam).
\end{abstract}

\section{Kata Kunci: Pendidikan, Islam, Keluarga.}

\begin{abstract}
${ }^{1}$ Dosen Sekolah Tinggi Ilmu Tarbiyah Madani Yogyakarta.

2Mahasiswa Sekolah Tinggi Ilmu Tarbiyah Madani Yogyakarta.

${ }^{3}$ Mahasiswa Sekolah Tinggi Ilmu Tarbiyah Madani Yogyakarta.
\end{abstract}

The purpose of this study is to explain the concept of family education according to Islam both from the goal to the method used in educating family members. The method in this research is descriptive qualitative with library research which is analytical descriptive. Data collection techniques using documentation techniques and analyzed 
through content analysis. The results of this study conclude 1) the purpose of Islamic education in the family is to uphold Islamic Shari'a in solving family problems, realize psychological tranquility, and meet the love needs of children, 2) methods of Islamic education in the family include exemplary, habituation and training, giving advice, and supervision. It can be concluded that parents have a great responsibility in educating, especially in protecting the family and maintaining family safety, and all of that will be successful if done based on Islamic law (Islamic education).

\section{Keywords: Education, Islam, Family.}

\section{A. Latar Belakang}

Pendidikan merupakan salah satu pilar kebangkitan suatu bangsa. Bahkan dalam pembukaan Undang-Undang Dasar Tahun 1945, secara jelas Negara menjadikan upaya mencerdaskan kehidupan bangsa sebagai tujuan Negara. Melihat dari tujuan tersebut, pemerintah berkewajiban untuk menyelenggarakan pendidikan dengan sebaik-baiknya. ${ }^{4}$ Pendidikan adalah sebuah usaha dalam membangun dan meningkatkan sumber daya manusia. Sumber daya manusia tidak mungkin berkembang dan maju tanpa pendidikan. ${ }^{5}$ Karena telah menjadi pendapat umum bahwa pendidikan adalah rancangan kegiatan yang paling banyak berpengaruh terhadap perubahan perilaku seseorang dan suatu masyarakat. Pendidikan berupaya mendidik manusia untuk

\footnotetext{
${ }^{4}$ M. Zainuddin, Paradigma Pendidikan Terpadu, (Malang: UIN Malang Press, 2008), hlm. 66 .

${ }^{5}$ Abd. Basir, Simpul- Simpul Pendidikan Islam Pada Sūrah Â li "Imrân, An-Nisã dan AlMâidah, dalam At- Tarbawi, Jurnal Kajian Kependidikan Islam, Vo 1.11.No. 2, (Nopember 2012-April 2013), hlm. 211
} 
mempunyai ilmu pengetahuan dan ketrampilan disertai dengan Iman dan Taqwa,sehingga dia akan memanfaatkan ilmu pengetahuan dan ketrampilan yang dimilikinya itu untuk kebaikan masyarakat,lingkungan dan bangsanya. ${ }^{6}$ Pendidikan merupakan model rekayasa sosial yang efektif untuk menyiapkan suatu bentuk masyarakat masa depan. Namun kenyataannya dewasa ini, pendidikan di dunia Islam mengalami krisis yang mengakibatkan kepada kemunduran. ${ }^{7}$

Para pemerhati pendidikan telah menganalisis beberapa sebab terjadinya kemunduran itu, di antaranya adalah karena ketidaklengkapan aspek materi, terjadinya krisis sosial dan budaya, hilangnya contoh teladan, hilangnya akidah yang benar dan nilai- nilai Islami. ${ }^{8}$

Terlebih lagi pendidikan tidak dapat dipisahkan dari kehidupan keluarga, sekolah dan masyarakat. sesuai dengan pendapat Hadirah bahwa pendidikan sangat berperan penting dalam kehidupan manusia tanpa pendidikan, manusia tak berdaya. Pada dasarnya pendidikan adalah usaha orang tua atau generasi tua untuk mempersiapkan anak atau generasi mudanya

\footnotetext{
${ }^{6}$ Muhamad Solikhodin Jaelani, Peran Pendidikan Agama Islam dalam Keluarga dan Masyarakat, Widya, Volume I No 2, Juli - Agustus 2013, hlm. 100

7 Ulil Amri Syafri.Pendidikan Karakter Berbasis Al-Qur"an, (Jakarta: Rajawali Pers, 2012), hlm. 1.

8 Ulil Amri Syafri. Pendidikan..., hlm. 2
} 
agar nantinya dapat hidup secara mandiri dan mampu melaksanakan tugas-tugas dalam hidupnya secara baik. ${ }^{9}$

Pendidikan Islam mulai dilaksanakan oleh Rasulullah SAW sebagai Muballigh Agung di tengah masyarakat di rumah arqam bin al arkam di Mekkah. Beliau mengajarkan tentang ajaran Islam dan semua ayat al-Qur'an yang diturunkan kepadanya, dengan membacakan secara berurutan dan bertahap, pendidikan Islam mempunyai sejarah panjang dan berkembang seiring dengan kemunculan Islam itu sendiri. Dalam konteks masyarakat Arab, dimana Islam lahir dan berkembang, kedatangan Islam sarat akan usaha-usaha pendidikan yang diupayakan untuk menanamkan nilai-nilai ajaran Islam dan sekaligus memperbaiki perilaku masyarakat Arab waktu itu (rahmatal lil 'alamin). ${ }^{10}$

Pendidikan Islam dalam era perkembangan ilmu pengetahuan dan teknologi dewasa ini semakin dipertanyakan keberadaan dan sumbangsihnya, apalagi bila dikaitkan dengan peran dan kontribusinya pada pembentukan budaya modern yang tentu saja sangat dipengaruhi dengan dinamika ilmu pengetahuan dan teknologi. Pendidikan di era modern ini lebih banyak menyentuh kecerdasan akliyat (aspek kognitif) dan kecerdasan ajsamiyat (aspek psikomotorik) dan kurang memerhatikan kecerdasan rukhiyat (afektif). Hal ini terbukti dari produktivitas pendidikan yang banyak melahirkan siswa dan kesarjanaan cerdas

9 Hadirah Ira, Dasar-dasar Kependidikan, (UIN Alauddin.Makassar : UIN Alauddin,2008) hlm. 5

10 Suwito, Sejarah Sosial Pendidikan Islam, (Jakarta: Prenada Media, 2005), hlm.5

112 | AT-TUROTS: Jurnal Pendidikan Islam 
dan terampil, tetapi masih banyak siswa yang tawuran, perkelahian, dan lain sebagainya serta masih banyak juga sarjana berdasi yang korupsi, menindas, maling hak rakyat. Semua kejadian ini adalah indikator bahwa pendidikan yang diperoleh belum lengkap. Walaupun ada yang berhasil tapi jumlahnya tidak banyak. Padahal Islam menuntut secara keseluruhan meskipun dengan bijak. ${ }^{11}$

Untuk itulah pendidikan agama Islam dalam keluarga menjadi sangat vital sebagaimana Menurut Zuhairini bahwa "pendidikan agama Islam ialah usaha-usaha secara sistematis dan pragmatis untuk membantu anak didik agar mereka hidup sesuai dengan ajaran agama. Sementara menurut Zakiah pendidikan agama Islam adalah sebagai berikut: "Pendidikan dengan melalui ajaran-ajaran agama Islam, yaitu bimbingan dan asuhan terhadap anak didik agar nantinya setelah selesai ia dapat memahami, menghayati dan mengamalkan ajaran-ajaran agama Islam yang telah diyakininya secara menyeluruh, serta menjadikan ajaran agama Islam itu sebagai suatu pandangan hidupnya demi keselamatan dan kesejahteraan hidup di dunia dan di akhirat kelak". Dengan demikian pendidikan agama Islam merupakan suatu usaha bimbingan dan asuhan terhadap anak didik agar nantinya dapat mengamalkan ajaran agamanya. Jadi dalam pendidikan agama Islam yang lebih dipentingkan adalah sebagai pembentukan kepribadian anak, yaitu menanamkan tabiat yang

${ }^{11}$ Ibid..., hlm.6 
baik agar anak didik mempunyai sifat yang baik dan berkepribadian yang utama. Tujuan pendidikan agama Islam adalah: (1) terbentuknya kepribadian yang utuh jasmani dan rohani (insan kamil) yang tercermin dalam pemikiran maupun tingkah laku terhadap sesama manusia, alam serta Tuhannya, (2) dapat menghasilkan manusia yang tidak hanya berguna bagi dirinya, tapi juga berguna bagi masyarakat dan lingkungan, serta dapat mengambil manfaat yang lebih maksimal terhadap alam semesta untuk kepentingan hidup di dunia dan akhirat, (3) merupakan sumber daya pendorong dan pembangkit bagi tingkah laku dan perbuatan yang baik, dan juga merupakan pengendali dalam mengarahkan tingkah laku dan perbuatan manusia. Oleh karena itu pembinaan moral harus didukung pengetahuan tentang ke-Islaman pada umumnya dan aqidah atau keimanan pada khususnya. ${ }^{12}$

Sebuah keniscayaan kiranya bahwa pendidikan harus dimulai dari lingkungan keluarga. Sebab keluarga merupakan lembaga masyarakat yang memegang peran sebagai kunci sosialisasi. ${ }^{13}$ Nilai dan karakter anggota keluarga sebagai bagian integral dari masyarakat banyak ditentukan oleh konsepsi dan pelaksanaan pendidikan dalam keluarga. Apabila pendidikan dalam keluarga berjalan dengan baik, tentu akan menghasilkan anggota keluarga yang baik, tetapi apabila

12 Solikhodin Jaelani, Peran Pendidikan..., hlm.101

13 Kamrani Buseri, Pendidikan Keluarga dalam Islam dan Gagasan Implementasinya, (Yogyakarta: Lanting Media Aksara Publishing House, 2010), hlm. 5

114 | AT-TUROTS: Jurnal Pendidikan Islam 
pendidikan tidak berjalan, maka hasilnya tidak bisa diharapkan menjadi manusia yang baik. Hal ini telah dinyatakan dan diisyaratkan oleh Allah swt. dalam al Quran sebagai kitab suci orang Islam yang wajib diamalkan. ${ }^{14}$

Allah berfirman di dalam al Quran sebagai berikut :

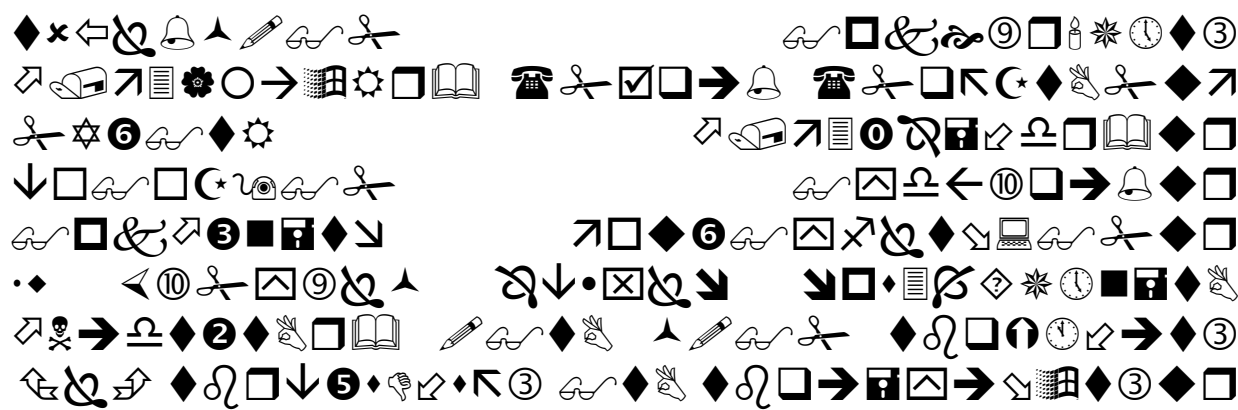
Artinya: "Wahai orang-orang yang beriman, peliharalah diri kalian dan keluarga kalian dari siksa neraka. Neraka itu bahan bakarnya adalah manusia dan berhala-berhala.malaikat yang kekar lagi kasar menjaga neraka. Para malaikat tidak pernah menyalahi perintah yang Allah berikan kepada mereka. Para malaikat senantiasa melaksanakan perintahNya."(QS. At-Tahrim : 6) $)^{15}$

Kebaikan yang Allâh perintahkan dalam ayat ini adalah, agar kaum Mukminin menjaga diri mereka dan keluarga mereka dari api neraka. Bagaimana caranya?

Abdullah bin Abbâs Radhiyallahu'anhu berkata, “Lakukanlah ketaatan kepada Allah dan jagalah dirimu dari kemaksiatan-kemaksiatan kepada Allah, dan perintahkan

\footnotetext{
14 Lihat Alquran Sūrat at-Taubah 9: 71. Allah swt. menegaskan bentuk tanggung jawab pendidikan keluarga. Keluarga mukmin dan mukminat diharuskan bekerja sama dalam amar makruf dan nahi munkar (dakwah), sholat, zakat dan kesiapan menaati Allah dan Rasul-Nya.

15 Muhammad Thalib, Al-Qur'ānul Karim Tarjamah Tafsiriyah (Yogyakarta: Ma'had An-Nabawy, 2011), hlm.561
} 
keluargamu dengan dzikir, niscaya Allâh Azza wa Jalla akan menyelamatkanmu dari neraka".

Mujahid rahimahullah berkata tentang firman Allah 'peliharalah dirimu dan keluargamu dari api neraka', “Bertakwalah kepada Allah, dan perintahkan keluargamu agar bertakwa kepada Allah Azza wa Jalla ".

Qatâdah rahimahullah berkata, "(Menjaga keluarga dari neraka adalah dengan) memerintahkan mereka untuk bertakwa kepada Allah dan melarang mereka dari kemaksiatan kepada Allah Azza wa Jalla , dan mengatur mereka dengan perintah Allah Azza wa Jalla, memerintahkan mereka untuk melaksanakan perintah Allah Azza wa Jalla, dan membantu mereka untuk melaksanakan perintah Allah. Maka jika engkau melihat suatu kemaksiatan yang merupakan larangan Allah, maka engkau harus menghentikan dan melarang keluarga(mu) dari kemaksiatan itu". ${ }^{16}$

Imam Ibnu Jarir Ath-Thabari rahimahullah berkata, “Allah Yang Maha Tinggi sebutannya berfirman, 'Wahai orang-orang yang membenarkan Allah dan RasulNya 'Peliharalah dirimu!', yaitu maksudnya, 'Hendaklah sebagian kamu mengajarkan kepada sebagian yang lain perkara yang dengannya orang yang kamu ajari bisa menjaga diri dari neraka, menolak neraka darinya, jika diamalkan. Yaitu ketaatan kepada Allah. Dan lakukanlah ketaatan kepada Allah.

16 Lihat semua riwayat di atas dalam Tafsir Ibnu Katsir, surat at-Tahrîm ayat ke-6 
Firman Allah 'dan keluargamu dari api neraka!', Maksudnya, 'Ajarilah keluargamu dengan melakukan ketaatan kepada Allah yang dengannya akan menjaga diri mereka dari neraka. Para ahli tafsir mengatakan seperti yang kami katakan ini.' [Tafsir ath-Thabari, 23/491]

Imam al-Alûsi rahimahullah berkata, "Menjaga diri dari neraka adalah dengan meninggalkan kemaksiatan-kemaksiatan dan melaksanakan ketaatan-ketaatan. Sedangkan menjaga keluarga adalah dengan mendorong mereka untuk melakukan hal itu dengan nasehat dan ta'dîb (hukuman) ... Yang dimaksukan dengan keluarga, berdasarkan sebagian pendapat mencakup: istri, anak, budak laki, dan budak perempuan. Ayat ini dijadikan dalil atas kewajiban seorang laki-laki mempelajari kewajiban-kewajiban dan mengajarkannya kepada mereka ini" ${ }^{17}$

\section{B. Pembahasan}

Penelitian berikut merupakan penelitian kualitatif deskriptif. Penelitian kualitatif deskriptif merupakan penelitian yang berusaha menemukan serta memeberikan gambaran teori yang berasal dari data. ${ }^{18}$ Oleh karena itu, teori yang digunakan dalam penelitian kualitatif deskriptif sangat berpengaruh. Baik dimulai dari penemuan fenomena sampai pada simpulan.

\section{Pendidikan Agama Islam}

\footnotetext{
${ }^{17}$ Lihat Tafsir al-Alûsi, 21/101 dan lihat Majalah As-Sunnah Edisi 12/Tahun XVII/1435H/2013M. (Surakarta : Yayasan Lajnah Istiqomah), hlm. 17

18 Maleong, Metodologi Penelitian Kualitatif. (Bandung: PT. Remaja Rosdakarya,2002), hlm.27-28.
} 


\section{a. Pengertian}

Istilah pendidikan berasal dari kata "didik" yang mendapat awalan "pe" dan akhiran "an" yang mengandung arti perbuatan (hal, cara, dan sebagainya). Istilah pendidikan merupakan terjemahan dari bahasa Yunani, yaitu Paedagogie, yang berarti bimbingan kepada anak didik. Istilah ini kemudian diterjemahkan ke dalam bahasa Inggris dengan istilah education yang berarti pengembangan atau bimbingan. Dalam bahasa Arab istilah ini sering diterjemahkan dengan kata Tarbiyah yang berarti pendidikan. ${ }^{19}$

Pendidikan berasal dari kata didik, lalu kata ini mendapat awal "me" sehingga menjadi "mendidik", artinya memelihara dan memberikan latihan. Dalam memelihara dan memberi latihan diperlukan adanya ajaran, tuntunan, dan pimpinan mengenai akhlak dan kecerdasan pikiran.

Pengertian pendidikan dalam kamus besar Bahasa Indonesia ialah proses pengubahan sikap dan tata laku seseorang atau kelompok orang dalam usaha mendewasakan menusia melalui upaya pengajaran dan pelatihan.

Dalam bahasa Inggris, education (pendidikan) berasal dari kata educate (mendidik) artinya memberikan peningkatan, dan mengembangkan. Dalam pengertian yang

\footnotetext{
19 Ramayulis, Ilmu Pendidikan Islam, (Jakarta: Kalam Mulia, 1994), Cet. 1, hlm. 1.
} 
sempit, education atau pendidikan berarti perbuatan atau proses perbuatan untuk memperoleh pengetahuan. ${ }^{20}$

Jadi yang dimaksud dengan Pendidikan ialah bimbingan atau pertolongan secara sadar yang diberikan oleh guru kepada peserta didik dalam usaha perkembangan jasmaniah dan rohaniah kearah kedewasaan dan seterusnya ke arah terbentuknya kepribadian muslim.

Pendidikan dalam arti sempit, ialah bimbingan yang diberikan kepada anak didik sampai ia dewasa. Sedangkan pendidikan dalam arti luas, ialah bimbingan yang diberikan sampai mencapai tujuan hidupnya, sampai terbentuknya kepribadian muslim. Jadi pendidikan Islam, berlangsung sejak anak dilahirkan sampai mencapai kesempurnaannya atau sampai akhir hidupnya. Sebenarnya kedua jenis pendidikan ini (arti sempit atau arti luas) satu adanya. ${ }^{21}$

Sedangkan menurut undang-undang sistem pendidikan nasional, pendidikan adalah usaha sadar dan terencana untuk mewujudkan suasana belajar dan proses pembelajaran agar peserta didik secara aktif mengembangkan potensi dirinya untuk memiliki kekuatan spiritual keagamaan, pengendalian diri, kepribadian,

20 Muhibbin Syah, Psikologi Pendidikan Dengan Pendekatan Baru, (Bandung: PT. Remaja Rosda Karya, 1997), hlm.256.

21 Ahmad D. Marimba, Pengantar Filsafat Pendidikan Islam, (Bandung: PT. Al-Ma.rif Bandung ), hlm. 31-32. 
kecerdasan akhlak mulia, serta keterampilan yang diperlukan dirinya, masyarakat, bangsa dan negara. ${ }^{22}$

22 UU Sistem Pendidikan Nasional, (Jakarta: Focus Media, 2003), hlm. 3.

120 | AT-TUROTS: Jurnal Pendidikan Islam 


\section{Landasan Pendidikan Agama Islam}

Di kalangan ulama terdapat kesepakatan bahwa sumber (landasan) pendidikan Islam secara garis besar ada 2 (dua) yaitu: Al-Quran, dan As-Sunnah. ${ }^{23}$

\section{a. Al-Quran}

Al-Quran ialah kalam Allah yang tiada tandingannya. Dan merupakan mu'jizat diturunkan kepada Muhammad S.A.W sebagai penutup para nabi, dengan perantaraan Malaikat Jibril, ditulis dalam mushaf-mushaf yang disampaikan kepada kita secara mutawatir, serta mempelajarinya merupakan suatu ibadah, dimulai dengan surat Al- Fatihah dan diakhiri dengan surat An-Nas.

Dalam Al-Quran banyak terdapat ayat-ayat pendidikan, ayat-ayat tersebut menyeru umat Islam untuk menuntut ilmu pengetahuan(pendidikan). Baik itu pendidikan untuk kepentingan yang bersifat duniawi maupun yang bersifat ukhrawi. Sebagaimana salah satu firman Allah yang terdapat dalam Al- Quran surat Al-Alaq ayat $1-5$ yang berbunyi:

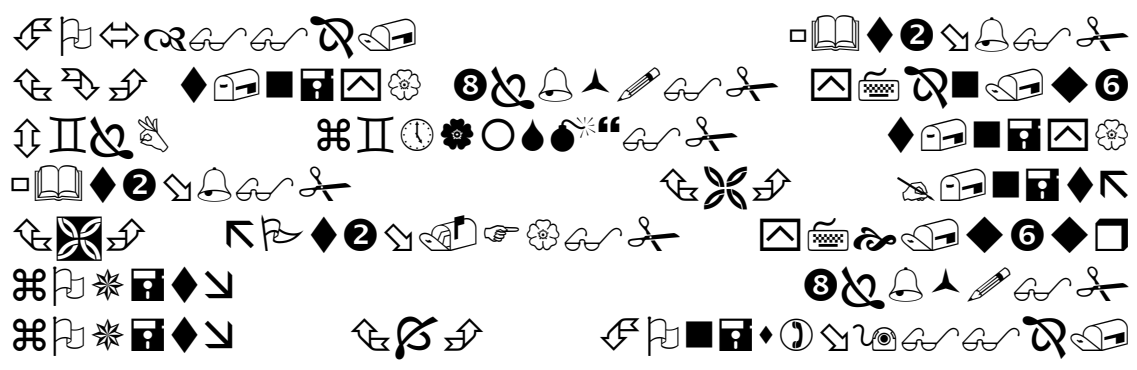

${ }_{23}$ Abuddin Nata, Metodologi Studi Islam, (jakarta: PT. Raja Grafindo Persada, 2007), hlm. 66 


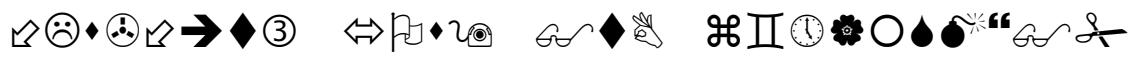

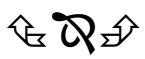

Artinya: "Bacalah dengan (menyebut) nama Tuhanmu yang menciptakan, Dia telah menciptakan manusia dari segumpal darah. Bacalah, dan tuhanmulah yang maha pemurah, yang mengajarkan kepada manusia apa yang tidak diketahuinya". (QS.al-Alaq: 1-5).

\section{b. As-Sunnah}

Dalam dunia pendidikan, Rasulullah juga turut menganjurkan umatnya untuk menuntut ilmu pengetahuan, sebagai bekal di dunia sampai ke akhirat kelak. "Menuntut ilmu adalah suatu kewajiban atas setiap muslim"(HR: Bukhari) $)^{24}$

Mencermati hadits di atas menunjukan bahwa, ilmu pengetahuan wajib dituntut, untuk dijadikan sebagai bekal dalam memasuki dunia yang penuh dengan problematika kehidupan, bahkan untuk mempersiapkan diri memasuki kehidupan yang lebih kekal dan abadi, yaitu kehidupan akhirat. ${ }^{25}$

\section{Tujuan Pendidikan Agama Islam}

Risnayanti dalam bukunya "Implementasi Pendidikan Agama Islam" mengemukakan 4 pakar Pendididkan Agama Islam yang memberikan tanggapan tentang tujuan pendidikan Agama Islam, diantaranya An-Nahlawy, Atiah Al- Abrasy' Al-

24 Jalaluddin Abdurrahman As-Sayuthi, Jaamil Al-Ahadits, (Beirut: Daarul Fikr, 1414), hlm.136.

25 Muhammad Atyhiyah Al-Abrasy, Beberapa Pemikiran Pendidikan Islam, (Yogyakarta: Titian Ilahi Press, 1996), hlm.5. 
Jamili, dan Ibnu Khaldun. ${ }^{26}$ Mereka mengemukakan sebagai berikut :

a. An-Nahlawy menunjukkan ada 5 tujuan pendidikan Islam yaitu:

1) Pendidikan akal dan persiapan pikiran, Allah menyuruh manusia merenungkan kejadian langit dan bumi agar beriman kepada Allah.

2) Menumbuhkan potensi-potensi dan bakat-bakat asal pada anak-anak. Karena Agama Islam agama yang fitrah.

3) Menaruh perhatian pada kekuatan dan potensi generasi muda dan mendidik mereka sebaik-baiknya, baik lakilaki ataupun perempuan.

4) Berusaha untuk menyeimbangkan segala potesi-potensi dan bakat bakat.

b. Al-Jammali menyebutkan 4 tujuan Pendidikan Agama Islam diantaranya:

1) Memperkenalkan kepada manusia akan kedudukannya di antara makhluk-makhluk dan bertanggung jawab perseorangan dalam hidup ini.

2) Memperkenalkan kepada manusia akan hubungan sosial dan tanggung jawabnya.

26 Risnayanti, Implementasi Pendidikan Agama Islam, (Jakarta: Perpustakaan Umum, 2004), hlm. 15-17. 
3) Memperkenalkan kepada manusia akan makhluk (alam semesta) dan mengajak manusia memahami hikmah penciptaannya.

4) Memperkenalkan kepada manusia akan pencipta alam maya, untuk mengenal Allah dan bertaqwa kepada-Nya.

c. Al-Abrasy menyimpulkan 4 tujuan bagi Pendidikan Agama Islam yakni:

1) Untuk mengadakan pembentukan akhlak yang mulia.

2) Persiapan untuk kehidupan dinia dan akhirat.

3) Persiapan untuk mencari rezeki dan pemeliharaan segi manfaat.

4) Menumbuhkan semangat ilmiah dalam jiwa pelajar itu mengkaji bukan sekedar ilmu.

5) Menumbuhkan semangat ilmiah dalam tubuh pelajar untuk mengkaji semua ilmu pengetahuan yang ada dalam jagat raya ini.

\section{Metode Pendidikan Agama Islam}

a. Abdul Fattah Jalal mengemukakan beberapa sistem pelaksanaan (Metodologi pendidikan Agama Islam) antara lain:

1) Metode contoh teladan

2) Metode keserasian antara ucapan dengan perbuatan

3) Metode pembiasaan

4) Metode pembiasaan suasana gembira

5) Metode analisa peristiwa 
6) Metode darmawisata. ${ }^{27}$

b. An-Nawawai dalam konteks metode pendidikan Agama Islam mengemukakan antara lain:

1) Metode hiwar

2) Metode al kisah (cerita)

3) Metode amsal (perumpamaan)

4) Metode teladan

5) Metode mengambil ibrah (pelajaran) dan mauidhah (peringatan)

6) Metode targhib ( membuat senang) dan tarhib (takut) 28

c. Zakiah Daradjat dalam bukunya "Metode Khusus Pengajaran Agama Islam" mengemukakan metode pendidikan sebagai berikut:

1) Metode ceramah

2) Metode diskusi

3) Metode eksperimen

4) Metode demonstrasi

5) Metode pemberian tugas

6) Metode sosiodrama

7) Metode drill (latihan)

8) Metode kerja kelompok

9) Metode tanya jawab. ${ }^{29}$

27 Abdul Fati Jalal, Azas Pendidikan Isalam, alih bahasa oleh Heri Neor Ali, Cet I, (Bandung, CV Ponorogo, 1986), hlm. 177

28 Samsul Nizar, Filsafat Pendidikan Islam Pendekatan Historis, Tioritis, Dan Praktis, (Jakarta: Ciputat Pres 2002), hlm. 73 


\section{Keluarga}

Pengertian Keluarga adalah merupakan kelompok primer yang paling penting dalam masyarakat. Keluarga merupakan sebuah grup yang terbentuk dari perhubungan laki-laki dan perempuan, perhubungan yang mana sedikit banyak berlangsung lama untuk menciptakan dan membesarkan anak-anak. Jadi keluarga dalam bentuk murni merupakan suatu kesatuan sosial yang terdiri dari suami, isteri dan anak-anak. ${ }^{30}$

Secara historis, keluarga terbentuk paling tidak dari satuan yang merupakan organisasi terbatas, dan mempunyai ukuran yang minimum, terutama pihak-pihak yang pada awalnya mengadakan suatu ikatan. Keluarga sebagai organisasi mempunyai perbedaan dengan organisasiorganisasi lainnya Salah satu perbedaan yang cukup penting terlihat dari bentuk hubungan anggota-anggotanya yang lebih bersifat lebih mendalam dan merupakan ciri - ciri kelompok primer antara lain:

a. Mempunyai hubungan yang lebih intim

b. Kooperatif

c. Face to face

${ }^{29}$ Zakiah daradjat, Metode khusus pangajaran agama islam, (Jakarta: Bumi Aksra, 2001), hlm. 289-307.

30 Abu Ahmadi, Ilmu Sosial Dasar. (Jakarta : Rineka Cipta, 2002), hlm. 239 
d. Masing-masing anggota memperlakukan anggota lainnya sebagai tujuan bukannya sebagai alat untuk mencapai tujuan.

Ciri-ciri lain juga dikemukakan oleh Paul H. Landis, adalah:

a. Intimate

b. Face to face

c. Warm hearted relationship

Dengan demikian keluarga mempunyai sistem jaringan interaksi yang lebih bersifat hubungan interpersonal, dimana masing-masing anggota dalam keluarga dimungkinkan mempunyai intensitas hubungan satu sama lain antara ayah dan ibu, ayah dan anak, ibu dan anak, maupun antara anak dan anak. Sistem interaksi antar pribadi (interpersonal) dapat digambarkan sebagai berikut :

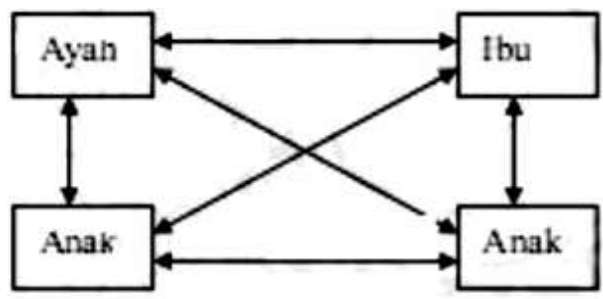

Gambar di atas dapat disimpulkan bahwa masingmasing anggota mempunyai jumlah hubungan yang sama terhadap anggota lainnya. ${ }^{31}$

${ }^{31}$ Khairuddin, Sosiologi Keluarga, (Yogyakarta : Liberty, 1997), hlm. 4-5 


\section{Fungsi-fungsi pokok keluarga}

Pada dasarnya keluarga mempunyai fungsi-fungsi pokok yakni fungsi yang sulit dirubah dan digantikan oleh orang lain. Sedangkan fungsi-fungsi lain atau fungsi-fungsi sosial, relatif lebih mudah berubah atau mengalami perubahan.

Fungsi-fungsi pokok tersebut antara lain :

a. Fungsi biologik

Keluarga merupakan tempat lahirnya anak-anak, fungsi ini merupakan dasar kelangsungan hidup masyarakat. Namun fungsi ini juga mengalami perubahan karena keluarga sekarang cenderung pada jumlah anak yang sedikit.

b. Fungsi afeksi

Dalam keluarga terjadi hubungan sosial yang penuh dengan kemesraan dan afeksi. Hubungan afeksi ini tumbuh sebagai akibat hubungan cinta kasih yang menjadi dasar perkawinan. Dari hubungan cinta kasih ini lahirlah hubungan persaudaraan, persahabatan, kebiasaan, identifikasi, persamaan pandangan mengenai nilainilai. Dasar cinta kasih dan hubungan afeksi ini merupakan faktor penting bagi perkembangan pribadi anak. Dalam masyarakat yang makin impersonal, sekuler, dan asing, pribadi sangat membutuhkan hubungan afeksi seperti yang 
terdapat dalam keluarga, suasana afeksi itu tidak terdapat dalam institusi sosial yang lain.

c. Fungsi sosialisasi

Fungsi sosialisasi menunjukkan peranan keluarga dalam kepribadian anak. Melalui interaksi sosial dalam keluarga, anak mempelajari pola-pola tingkah laku, sikap, keyakinan, cita-cita dan nilai-nilai dalam masyarakat dalam rangka perkembangan kepribadiannya. ${ }^{32}$

\section{Pendidikan Islam dalam Keluarga}

Dalam islam, keluarga dikenal dengan istilah "usrah". sedangkan menurut pandangan antropologi keluarga adalah suatu kesatuan sosial terkecil yang dimiliki oleh manusia sebagai makhluk sosial yang memiliki tempat tinggal untuk berlindung, mendidik, berkembang, dan lain sebagainya. Inti sebuah keluarga adalah ayah, ibu dan anak. ${ }^{33}$

Keluarga muslim adalah keluarga yang mendasarkan aktivitasnya pada pembentukan keluarga yang sesuai dengan syariat islam, menurut Abdurrahman An-Nahlawi, tujuan terpenting dari pembentukan keluarga adalah sebagai berikut:

a. Mendirikan syariat allah dalam segala permasalahan rumah tangga.

b. Mewujudkan ketenteraman dan ketenangan psikologi.

32 Khairuddin, Sosiologi...hlm.48-49

${ }_{33}$ Husein Muhammad Yusuf, Keluarga Muslim dan Tantangannya, (Jakarta : Gema Insani Press, 2001), hlm.19 
c. Mewujudkan sunnah rasul dengan melahirkan anak-anak shaleh sehingga rasul merasa bangga dengan kehadiran kita.

d. Memenuhi kebutuhan cinta kasih anak.

e. Menjaga fitrah anak agar tidak melakukan peyimpanganpenyimpangan.

Dalam lingkungan keluarga terletak dasar-dasar pendidikan. di sini pendidikan berlangsung dengan sendirinya sesuai tatanan pergaulan yang berlaku didalamnya, artinya tanpa harus diumumkan atau ditulis terlebih dahulu agar diketahui dan diikuti oleh seluruh anggota keluarga . di sini diletakkan dasar-dasar pengalaman melalui rasa kasih sayang dan penuh kecintaan, kebutuhan akan kewibawaan dan nilainilai kepatuhan. justru karena pergaulan yang demikian itu berlangsung dalam hubungan yang bersifat pribadi dan wajar, maka penghayatan terhadapnya mempunyai arti yang amat penting. Jadi, pendidikan Islam dalam keluarga yaitu pendidikan yang diberikan anggota kelurga terutama orang tua kepada anaknya dalam lingkungan keluarga itu sendiri untuk membentuk kepribadian anak menjadi muslim dengan adanya perubahan sikap dan tingkah laku yang sesuai dengan ajaran Islam. ${ }^{34}$

Keluarga merupakan unit sosial terkecil yang utama dan pertama bagi seorang anak, sebelum ia berkenalan dengan

\footnotetext{
34 https://arrywijayanti.wordpress.com/2012/11/09/pendidikan-islam-dalamkeluarga/diakses 10 november 2016
} 
dunia sekitarnya, ia akan berkenalan telebih dahulu dengan situasi keluarga. Pengalaman pergaulan dalam keluarga akan memberikan pengaruh yang sangat besar bagi perkembangan anak untuk masa yang akan datang. Keluargalah yang akan memberikan warna kehidupan seorang anak, baik perilaku, budi pekerti maupun adat kebiasaan sehari-hari. Keluarga jualah tempat dimana seorang anak mendapat tempaan pertama kali yang kemudian menentukan baik buruk kehidupan setelahnya di masyarakat. Sehingga tidak salah lagi kalau keluarga adalah elemen penting dalam menentukan baik-buruknya masyarakat. ${ }^{35}$

Keluarga adalah wadah pertama dan utama bagi pertumbuhan dan pengembangan anak. Jika suasana dalam keluarga itu baik dan menyenangkan, maka anak akan tumbuh dengan baik pula. Jika tidak, tentu akan terhambatlah pertumbuhan anak tersebut. Peranan orang tua dalam keluarga amat penting, terutama ibu. Dialah yang mengatur, membuat rumah tangganya menjadi surga bagi anggota keluarga, menjadi mitra sejajar yang saling menyayangi dengan suaminya. ${ }^{36}$ Dalam hal ini peranan seorang ibu sangat besar dalam menentukan keberhasilan karier anaknya sebagai anak yang berguna bagi keluarga, masyarakat, agama, bangsa dan

35 Athiyah Al-Abrasy, Dasar-dasar Pokok Pendidikan Islam, (Jakarta: Bulan Bintang, 1993), hlm.133

36 Zakiah Daradjat, Pendidikan Islam dalam Keluarga dan Sekolah, (Bandung: CV Ruhama, 1995), hlm.47 
negara. Orang tua merupakan pendidik utama dan pertama bagi anak-anak mereka, karena dari merekalah anak mulai menerima pendidikan. Dengan demikian bentuk pertama dari pendidikan terdapat dalam kehidupan keluarga. Dalam hal ini faktor penting yang memegang peranan dalam menentukan kehidupan anak adalah pendidikan orang tua. yang selanjutnya digabungkan menjadi pendidikan agama. Pada setiap anak terdapat suatu dorongan dan suatu daya untuk meniru. Dengan dorongan ini anak dapat mengerjakan sesuatu yang dikerjakan oleh orang tuanya. Oleh karena itu, orang tua harus menjadi teladan bagi anak-anaknya. Apa saja yang didengarnya dan dilihat selalu ditirunya tanpa mempertimbangkan baik dan buruknya. Dalam hal ini sangat diharapkan kewaspadaan serta perhatian yang besar dari orang tua. Karena masa meniru ini secara tidak langsung turut membentuk watak dan karakter anak di kemudian hari. Sebagaimana Rasulullah SAW, bersabda: dari Abu Hurairah, r.a., berkata: Bersabda Rasulullah SAW.: "Tidaklah seseorang yang dilahirkan melainkan menurut fitrahnya, maka kedua orang tuanyalah yang meyahudikannya atau menasronikannya atau memajusikannya" (HR. Bukhari).

Dalam pandangan Islam, anak adalah amanat yang dibebankan oleh Allah SWT kepada orang tuanya, karena itu orang tua harus menjaga dan memelihara serta menyampaikan amanah itu kepada yang berhak menerima. Karena manusia 
adalah milik Allah SWT, mereka harus mengantarkan anaknya untuk mengenal dan menghadapkan diri kepada Allah SWT. Mengingat strategisnya jalur pendidikan keluarga, dalam Undang-undang Sistem Pendidikan Nasional (UUSPN, ps. 10. 5) juga disebutkan arah yang seharusnya ditempuh yakni: pendidikan keluarga merupakan bagian dari jalur pendidikan luar sekolah yang diselenggarakan dalam keluarga, dan memberikan keyakinan agama, nilai budaya, nilai moral dan keterampilan. ${ }^{37}$

Pendidikan keluarga diharapkan dapat menjadi sarana pembentukan karakter dan kepribadian anak menjadi manusia yang utuh, yaitu manusia yang berbudi luhur, cerdas, dan terampil. Sehingga, di masa mendatang anak tersebut menjadi manusia yang baik, anggota masyarakat dan warga Negara yang baik. Pendidikan agama (khususnya agama Islam) merupakan pendidikan yang sangat sesuai untuk diterapkan dalam rangka pembentukan karakter (akhlak) anak. Karena di dalam pendidikan agama Islam mencakup pendidikan nilai budi pekerti, nilai keyakinan (aqidah), dan nilai pengabdian (ibadah).

Tugas orang tua untuk mendidik keluarga khususnya anak-anak, secara umum Allah SWT tegaskan dalam al-Qur'an surat At Tahrim (66) ayat 6:

37 Abdullah Nashih Ulwan, Tarbiyatul -Aulad fil Islam, Terj. Khalilullah Ahmas Masjkur Hakim, Pendidikan Anak Menurut Islam; Kaidah-kaidah Dasar, Cet. I (Bandung; Remaja Rosdakarya, 1992), hlm. 45 
$\checkmark x$ एकी क्ष \&

祭\&四口 $\rightarrow$ \&

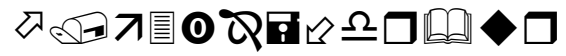

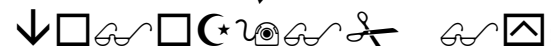

G $\square \&$ \&3

- <(10) \&

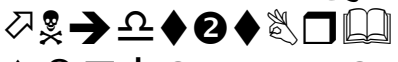

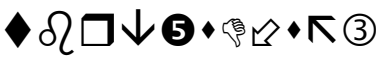

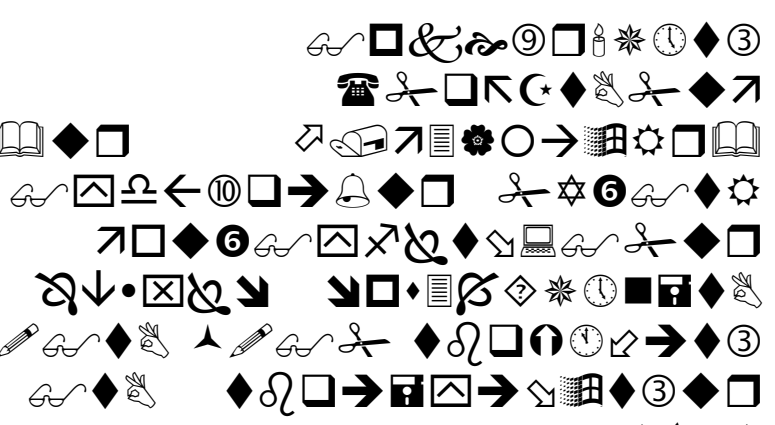

ثिd式

Artinya: "Wahai orang-orang yang beriman, peliharalah diri kalian dan keluarga kalian dari siksa neraka. Neraka itu bahan bakarnya adalah manusia dan berhala-berhala.malaikat yang kekar lagi kasar menjaga neraka. Para malaikat tidak pernah menyalahi perintah yang Allah berikan kepada mereka. Para malaikat senantiasa melaksanakan perintah-Nya."(QS. At-Tahrīm : 6) ${ }^{38}$

\section{Metode Pendidikan Islam dalam Keluarga}

a. Mendidik dengan keteladanan (contoh)

Keteladanan dalam pendidikan merupakan bagian dari sejumlah metode yang paling efektif dalam mempersiapkan dan membentuk anak secara moral, spiritual dan sosial. Seorang pendidik merupakan contoh ideal dalam pandangan anak yang tingkah laku dan sopan santunnya akan ditiru, bahkan semua keteladanan itu akan melekat pada diri dan perasaannya. Apabila kita perhatikan cara Luqman mendidik anaknya yang terdapat dalam surat Luqman ayat 15 bahwa nilai-nilai agama mulai dari penampilan pribadi luqman yang beriman, beramal saleh, bersyukur kepada Allah Swt dan bijaksana dalam segala hal, kemudian yang di didik dan di nasehatkan kepada anaknya

38 Muhammad Thalib, Al-Qur'ānul Karim...hlm. 561 
adalah kebulatan iman kepada Allah Swt semata, akhlak dan sopan santun terhadap kedua orang tua, kepada manusia dan taat beribadah.

Sehubungan dengan hal tersebut, hendaklah orang tua selaku memberikan contoh yang ideal kepada anakanaknya, sering terlihat oleh anak melaksanakan sholat, bergaul dengan sopan santun. Berbicara dengan lemah lembut dan lainlainnya. Dan semua itu akan ditiru dan dijadikan contoh oleh anak.

b. Mendidik dengan adab pembiasaan dan latihan.

Setiap anak dalam keadaan suci, artinya ia dilahirkan di atas fitrah (kesucian) bertauhid dan beriman kepada Allah Swt. Oleh karena itu menjadi kewajiban orang tua untuk memulai dan menerapkan kebiasaan, pengajaran dan pendidikan serta menumbuhkan dan mengajak anak kedalam tauhid murni dan akhlak mulia. Hendaknya setiap orang tua menyadari bahwa dalam pembinaan pribadi anak sangat diperlukan pembiasaan-pembiasaan dan latihanlatihan yang cocok dan sesuai dengan perkembangan jiwanya. Karena pembiasaan dan latihan itu akan membentuk sikap tertentu pada anak, yang lambat laun sikap itu akan terlihat jelas dan kuat, sehingga telah masuk menjadi bagian dari pribadinya.

Di sinilah bahwa pembiasaan dan latihan sebagai suatu cara atau metode mempunyai peranan yang sangat 
besar sekali dalam menanamkan pendidikan pada anak sebagai upaya membina akhlaknya. Peranan pembiasaan dan latihan ini bertujuan agar ketika anak tumbuh besar dan dewasa, ia akan terbiasa melaksanakan ajaran-ajaran agama dan tidak merasa berat melakukannya. Pembiasaan dan latihan jika dilakukan berulang-ulang maka akan menjadi kebiasaan, dan kebiasaan itulah yang nantinya membuat anak cenderung melakukan yang baik dan meninggalkan yang buruk dengan mudah.

c. Mendidik dengan nasehat

Di antara mendidik yang efektif di dalam usaha membentuk keimanan anak, mempersiapkan moral, psikis dan sosial adalah mendidik dengan nasehat. Sebab nasehat ini dapat membukakan mata anak-anak tentang hakikat sesuatu dan mendorongnya menuju situasi luhur, menghiasinya dengan akhlak mulia, serta membekalinya dengan prinsip-prinsip Islam. ${ }^{39}$ Nasehat yang tulus berbekas dan berpengaruh jika memasuki jiwa yang bening, hati terbuka, akal yang bijak dan berpikir. Nasehat tersebut akan mendapat tanggapan secepatnya dan meniggalkan bekas yang dalam. Al Qur'an telah menegaskan pengertian ini dalam banyak ayatnya, dan berulang kali menyebutkan manfaat dari peringatan dengan kata-kata yang mengandung petunjuk dan nasehat yang tulus, di antaranya:

${ }^{39}$ Ibid.,hlm.66 
"Sungguh kejadian yang menimpa umat-umat dahulu menjadi peringatan bagi orang yang mempunyai hati, atau orang yang memiliki pendengaran, lagi mau berpikir cerdas." (QS. Qaaf : $37)^{40}$

"Dan tetaplah memberi peringatan, karena sesungguhnya peringatan itu bermanfa'at bagi orang-orang yang beriman".(QS.Adz-Dzariyat : 55$)^{41}$

Nasehat sangat berperan dalam menjelaskan kepada anak tentang segala hakekat serta menghiasinya dengan akhlak mulia. Nasehat orang tua jauh lebih baik dari pada orang lain, karena orang tualah yang selalu memberikan kasih sayang serta contoh perilaku yang baik kepada anaknya. Disamping memberikan bimbingan serta dukungan ketika anak mendapat kesulitan atau masalah, begitupun sebaliknya ketika anak mendapatkan prestasi.

d. Mendidik dengan pengawasan

Pendidikan yang disertai pengawasan yaitu mendampingi anak dalam upaya membentuk akidah dan moral, mengasihinya dan mempersiapkan secara psikis dan sosial, memantau secara terus menerus tentang keadaannya baik dalam pendidikan jasmani maupun dalam hal belajarnya. Mendidik yang disertai pengawasan bertujuan untuk melihat langsung tentang bagaimana keadaan tingkah laku anak sehari-harinya baik di lingkungan keluarga maupun sekolah. Di lingkungan keluarga hendaknya anak

40 Muhamad Thalib, Al-Qur'ānul Karim..hlm.521

41 Ibid.,hlm.524. 
tidak selalu dimarahi apabila ia berbuat salah, tetapi ditegur dan dinasehati dengan baik. Sedangkan di lingkungan sekolah, pertama-tama anak hendaknya diantar apabila ia ingin pergi ke sekolah. Supaya ia nanti terbiasa berangkat kesekolah dengan sendiri. Begitu pula setelah anak tiba di rumah ketika pulang dari sekolah hendaknya ditanyakan kembali pelajaran yang ia dapat dari gurunya.

Dari penjelasan di atas dapat disimpulkan bahwa orang tua mempunyai tanggung jawab besar dalam mendidik, khususnya di dalam melindungi keluarga dan memelihara keselamatan keluarga. Melindungi keluarga bukan hanya memberikan tempat tinggal saja, tetapi memberikan perlindungan supaya keluarga kita terhindar dari mala petaka baik didunia maupun di akherat nanti yaitu dengan cara mengajak keluarga kita kepada perbuatan-perbuatan yang perintahkan oleh Allah SWT dan menjauhi segala larangan-larangannya. Memelihara keselamatan keluarga yaitu mengajarkan keluarga kita supaya taat kepada Allah SWT, agar keluarga kita diberikan keselamatan oleh Allah SWT baik di dunia dan akherat.

Oleh karena itu pelaksanaan pendidikan agama Islam dalam keluarga harus benar-benar dilaksanakan. Dan sebagai orang tua harus menjadi contoh yang baik bagi anak-anknya, karena anak itu sifatnya menerima semua yang dilkukan, yang dilukiskan dan condong kepada semua 
yang tertuju kepadanya. Jika anak itu dibiasakan dan diajari berbuat baik maka anak itu akan hidup bahagia di dunia dan di akherat. Tetapi jika dibiasakan berbuat jahat dan dibiarkan begitu saja, maka anak itu akan celaka dan binasa. Maka yang menjadi ukuran dari ketinggian anak itu ialah terletak pada yang bertanggung jawab (pendidik) dan walinya.

\section{Kesimpulan}

Berdasarkan paparan di atas, dapat disimpulkan bahwa orang tua mempunyai tanggung jawab besar dalam mendidik, khususnya di dalam melindungi keluarga dan memelihara keselamatan keluarga,dan semua itu akan sukses jika dilakukan dengan berlandaskan pada syariat Islam yang dijabarkan dalam proses pendidikan Islam. 


\section{DAFTAR ISI}

Abdurrahman As-Sayuthi, Jalaluddin, 1414. Jaamil Al-Ahadits, Beirut: Daarul Fikr

Ahmadi, Abu, 2002. Ilmu Sosial Dasar, Jakarta: Rineka Cipta.

, dkk 1993. Dasar-Dasar Pendidikan Agama Islam, Jakarta: Bumi Aksara

Al-Abrasy, Athiyah, 1993. Dasar-dasar Pokok Pendidikan Islam, Jakarta: Bulan Bintang 1996. Beberapa Pemikiran Pendidikan Islam, Yogyakarta: Titian Ilahi Press.

Amri Syafri, Ulil, 2012. Pendidikan Karakter Berbasis Al-Qur'an, Jakarta: Rajawali Pers

Arifin, M. 1978. Hubungan Timbal Balik Pendidikan Agama di lingkungan sekolah dan keluarga, Jakarta: Bulan Bintang

Ashraf, Ali, 1989. Horison Baru Pendidikan Islam, Jakarta : Pustaka Progresif

Azra, Azyumardi, 1998. Esei-Esei Intelektual Muslim dan Pendidikan Islam, Jakarta: Logos

Hunsberger, Bruce. 1984 "Religious Socialization, Apostacy, and the Impact on Family Background." Journal for the Scientific Study of Religion 23, no. 3

Basir, Abd, Nopember 2012-April 2013. Simpul- Simpul Pendidikan Islam Pada Sūrah Âli Imrân, An-Nisã dan AlMâidah, dalam AtTarbawi, Jurnal Kajian Kependidikan Islam Vol 1.11.No. 2

Budiman, M. Nasir, 2001. Pendidikan dalam Prefektif al-qur'an, Cet I, Jakarta: Maduel press 
Hafidz, Rizky Kurnia Ahmad, Ajeng Vivi Santika

Buseri, Kamrani, 1990. Pendidikan Keluarga Dalam Islam, Yogyakarta: Bina Usaha

2010. Pendidikan Keluarga dalam Islam dan Gagasan Implementasinya, Yogyakarta: Lanting Media Aksara Publishing House

D Marimba, Ahmad, 1962. Pengantar Filsafat Pendidikan Islam, Bandung: Al-Ma'arif

Daradjat, Zakiah, 1995. Pendidikan Islam dalam Keluarga dan Sekolah, Bandung: CV Ruhama

2001. Metode khusus pangajaran agama islam, Jakarta: Bumi Aksra.

Flor, Douglas L, 2001. "Transmission and Transaction: Predicting Adolescents'Internalization of Parental Religious Values." Journal of Family Psychology 15, no. 4

Faudzil Adhim, Mohammad, 2001. Mencapai Pernikahan Barakah, Cetakan X, Yogyakarta: Mitra Pustaka.

Fu'ad Abdul Baqi, Muhammad, 2005. Mutiara Hadits, Alih bahasa dari Al-Lu'lu Warmajan, Surabaya: PT Bina Ilmu.

Gerungan, WA, 2004. Psikologi Sosial, Bandung: Refika Aditama

Ibrahim Muhanna, Ahmad, 1982. Al-Tarbiyah fi Al- Islam, Cairo: Dar Al-Sya'bi

Ira, Hadirah, 2008. Dasar-dasar Kependidikan, Makassar : UIN Alauddin

Jalal, Abdul Fati, 1986. Azas Pendidikan Isalam, alih bahasa oleh Heri Neor Ali, Cet I, Bandung, CV Ponorogo.

Khairuddin, 1997. Sosiologi Keluarga, Yogyakarta: Liberty

Majalah As-Sunnah, Tahun XVII/1435H/2013M Edisi 12, Surakarta : Yayasan Lajnah Istiqomah. 
Maleong, 2002. Metodologi Penelitian Kualitatif, Bandung: PT. Remaja Rosdakarya

Muhammad Naufal, Abu Ahmad, 1994. Langkah Mencapai Kebahagiaan Berumah Tangga, Yogyakarta: Al Husna Press

Muhammad Thalib, 2011. Al-Qur'ānul Karim Tarjamah Tafsiriyah, Yogyakarta: Ma'had An-Nabawy.

Musthafa, Ibnu, 1992. Keluarga Islam Menyongsong Abad 21, Jakarta: AlBayan

Nashih Ulwan, Abdullah, 1992. Tarbiyatul -Aulad fil Islam, Terj. Khalilullah Ahmas Masjkur

Hakim, Pendidikan Anak Menurut Islam; Kaidah-kaidah Dasar, Cet. I, Bandung: Remaja Rosdakarya

Kaidah-kaidah dasar (Pendidikan anak menurut Islam), Bandung: Remaja Rosdakarya

Nasution, Harun, 1985. Islam Ditinjau Dari Berbagai Aspeknya, Jakarta: UI-Press

Nata, Abuddin, 2007. Metodologi Studi Islam, Jakarta: PT. Raja Grafindo Persada

Nizar, Samsul, 2002. Filsafat Pendidikan Islam Pendekatan Historis, Tioritis, Dan Praktis, Jakarta: Ciputat Pres.

Noer Ali, Hery, 1999. Ilmu Pendidikan Islam, Jakarta: Logos

Rahmat, Jalaluddin, 2003. Wawasan Islam, Pradikma Dan Sistem Islam, Bandung: Matahari Press.

, 1994. Keluarga Muslim dalam Masyarakat Moderen, Bandung: PT. Remaja Rosdakarya.

Ramayulis, 1994. Ilmu Pendidikan Islam, Jakarta: Kalam Mulia 
Hafidz, Rizky Kurnia Ahmad, Ajeng Vivi Santika

Razak, Nasrudin, 1993. Dinul Islam, Cet. II, Bandung: Al-ma'arif

Risnayanti, 2004. Implementasi Pendidikan Agama Islam, Jakarta: Perpustakaan Umum

Rosyada, Dede, 1992. Hukum Islam Dan Pranata Sosial,"Dirasah Islamiyah", Jakarta: raja grafindo persada

Shaleh, Abdul Rachman, 2000. Pendidikan Agama dan Keagamaan, Jakarta: Gemawindu Pancaperkasa

Shihab, M. Quraish, 1992. Membumikan Al-Quran, Bandung: Mizan

Solikhodin Jaelani, Muhammad, Juli - Agustus 2013. Peran Pendidikan Agama Islam dalam Keluarga dan Masyarakat, Widya, Volume I No 2

Suwito, 2005. Sejarah Sosial Pendidikan Islam, Jakarta: Prenada Media

Syah, Muhibbin, 1997. Psikologi Pendidikan Dengan Pendekatan Baru, Bandung: PT. Remaja Rosda Karya

Tafsir, Ahmad, 1999. Metodologi Pengajaran Agama Islam, Bandung: Remaja Rosdakarya

Thalib, Muhammad, 2011. Al-Qur'ānul Karim Tarjamah Tafsiriyah, Yogyakarta: Ma'had An-Nabawy

Wijayanti, arry, 2012. "Pendidikan Islam dalam Keluarga", https://arrywijayanti. wordpress.com /2012/11/09/ pendidikan-islam-dalam-keluarga, diakses 10 november 2016

Yusuf, Husein Muhammad, 2001. Keluarga Muslim dan Tantangannya, Jakarta: Gema Insani Press

Zaenul Fitri, Agus, 2012/1433. Keluarga Sebagai Lembaga Pertama Pendidikan Islam, Jurnal Pendidikan Islam, Vol. XVII No. 1

Zainuddin, Muhammad, 2008. Paradigma Pendidikan Terpadu, Malang: UIN Malang Press 
Pendidikan Keluarga Menurut Islam

144 | AT-TUROTS: Jurnal Pendidikan Islam 